\title{
Pathological tissue processing time vs. morbidity and mortality
} Andrew Riskalla, Waseem Jerjes*, Tahwinder Upile, Farai Nhembe, Priya Shah, Shinali Patel, Ann Sandison and Colin Hopper

Address: UCLH Head \& Neck Centre, London, UK

* Corresponding author

from Ist Scientific Meeting of the Head and Neck Optical Diagnostics Society

London, UK. I4 March 2009

Published: 28 July 2009

Head \& Neck Oncology 2009, I(SuppI I):P20 doi:I0.II86/I758-3284-I-SI-P20

This abstract is available from: http://www.headandneckoncology.org/content/I/SI/P20

(C) 2009 Riskalla et al; licensee BioMed Central Ltd.

\section{Background}

It is well documented that delay in diagnosing tumours in the head and neck region can affect morbidity and mortality. Delay in processing a biopsy can also affect the patient as it can delay surgical treatment or adjunct therapy.

\section{Methods}

We have retrospectively analysed information acquired from 168 patients treated following recurrent squamous cell cancer. Pathological tissue processing time was identified at 4 intervals (first diagnostic biopsy, first surgical resection, second diagnostic biopsy for recurrence and second surgical resection). This was compared to primary sites, recurrence sites, TNM staging and survival over 3 and 5 years.

\section{Results}

We show that the processing time for the biopsy of the original and recurrence does have a significant effect on prognosis $(\mathrm{p}<0.01)$.

\section{Conclusion}

The Royal College of Pathologists have released recent guidelines as to the quality of their delivered head and neck pathology reports however little guidance has been given as to timing. We now show that delay does have an adverse prognostic effect. 